\title{
3. LARGER FORAMINIFERAL BIOSTRATIGRAPHY OF SITES 815, 816, AND 826, LEG 133, NORTHEASTERN AUSTRALIA ${ }^{1}$
}

\author{
George C.H. Chaproniere ${ }^{2}$ and Christian Betzler ${ }^{3}$
}

\begin{abstract}
The Marion Plateau is a large carbonate platform off northeastern Queensland. Three sites $(815,816$, and 826$)$ were drilled on this platform and form the basis for this study. Larger benthic foraminifers, together with rare planktonic forms from the shallow-water carbonates that form the main part of the platform sequence, were studied to establish a biostratigraphy. The presence of Lepidocyclina (Nephrolepidina) howchini sensu lato and Ladoronia vermicularis, together with Globorotalia (Globorotalia) praemenardii and Orbulina, indicate an early middle Miocene (N9-N12) age (i.e., lower Tf stage) for these carbonates. Dolomitization has destroyed much of the original fabric of these carbonates, making study of the larger foraminifers difficult. Sites 815 (forereef location) and 826 (backreef, lagoonal setting) provide the best faunas. However, at all sites nodular coralline algae and Halimeda are the major bioclasts; coral fragments form a major component at Sites 816 and 826 . The middle Miocene neritic sequence is separated from the overlying hemipelagic sequence by an unconformity that spans much of the middle and late Miocene. At Site 815, which is in a forereef situation, the overlying hemipelagic sequence contains a Zone N17A fauna. but at Site 816, higher on the platform, a similar sequence contains a Zone N19 fauna. The faunas indicate that the platform was built up during the early middle Miocene and remained at fairly constant water depths and temperatures during this period. It was then exposed prior to subsiding rapidly during the late Miocene and Pliocene to depths similar to those of the present day.
\end{abstract}

\section{INTRODUCTION}

Three sites were drilled on the Marion Plateau during Leg 133 (Fig. 1). Site 815 is situated on the northwestern margin of the plateau and penetrated a 473.5 -m-thick forereef sequence. The upper $416 \mathrm{~m}$ are upper Miocene to Pleistocene hemipelagic sediments unconformably overlying a sequence of platform carbonates, of which $57.5 \mathrm{~m}$ was penetrated. Site 816 is located on the northwestern corner of the Marion Plateau and penetrated $250 \mathrm{~m}$ of sediment. The upper $93 \mathrm{~m}$ are early Pliocene to Pleistocene hemipelagic sediments overlying a reefal carbonate platform sequence. Site 826 is located on the northern margin of the plateau adjacent to Site 816 , but in a lagoonal or back-reef location. About $98.5 \mathrm{~m}$ of hemipelagic sediments overlie the platform carbonates.

The objectives of this study are (1) to describe the larger foraminiferal faunas from the platform sequence and (2) to describe the biostratigraphic record and to determine the probable depth of deposition. Some biostratigraphic information is known for the platform carbonates of the Marion Plateau from previous dredging operations in the region (Chaproniere and Pigram, in press). One of the Leg 133 drilling objectives in the region was to establish a complete stratigraphic sequence from the area. Although the dredge samples showed some recrystallization effects, these were much less than those found in the samples obtained from drilling. In some cases, this dolomitization has obliterated the fauna, and in others, has made it very difficult to identify taxa accurately. This has severely restricted the biostratigraphic resolution. In Figure 2, we summarize the biostratigraphic results, while Tables 1 through 5 illustrate the distribution of foraminifers at the sites and holes.

Because we know from previous studies that a major unconformity occurred between the platform phase of sedimentation and the overlying hemipelagic sequence, it was critical for us to date the interval of time represented by the hiatus using information from the drilling samples. For this reason, the planktonic foraminifers from the

\footnotetext{
'McKenzie, J.A., Davies, P.J., Palmer-Julson, A., et al., 1993, Proc. ODP, Sci. Results. 133: College Station, TX.

${ }^{2}$ Marine Geoscience Program, Bureau of Mineral Resources, P.O. Box 378, Canberra, ACT 2601, Australia.

${ }^{3}$ Geologisches Paläontologisches Institut. Senckenberganlage 32-34, D-6000 Frankfurt-am-Main 11. Federal Republic of Germany.
}

hemipelagic sequence immediately overlying the platform sequence also were studied.

\section{METHODS}

The planktonic foraminiferal zonal scheme of Blow (1969) as modified by Kennett and Srinivasan (1983), has been used within this study, and the letter stage scheme, as modified by Adams (1984) and Chaproniere (1981, 1984), has been employed for the larger foraminifers (Fig. 2). In addition, Parameter F for Lepidocyclina (Nephrolepidina) howchini sensu lato (Chaproniere, 1981, 1984) has also been used. Faunas from the hemipelagic samples overlying the platform sequence were washed and disaggregated using standard preparation techniques. The assemblages from the carbonate sequence could be studied only from random thin sections.

The lithologic descriptions of the units from which the studied samples were taken are those used in Davies, McKenzie, PalmerJulson, et al. (1991). All figured specimens are registered and housed in the Commonwealth Palaeontological Collection (CPC), Bureau of Mineral Resources, Canberra, Australia.

\section{FAUNAL ASSEMBLAGES}

\section{Site $\mathbf{8 1 5}$}

At this site, both a hemipelagic sequence and underlying platform carbonates were penetrated. The platform carbonates were dolomitized bioclastic rudstones to floatstones and planktonic foraminiferal packstone. The dolomitization had seriously affected the quality of faunal preservation.

Six samples were studied from Hole 815A. Five of these are late Miocene in age (Samples 133-815A-46X-2, 27-28 cm, -47A-2, 80$82 \mathrm{~cm},-48 \mathrm{X}-1,45-47 \mathrm{~cm},-48 \mathrm{X}-\mathrm{CC}, 15-16 \mathrm{~cm}$, and $-48 \mathrm{X}-\mathrm{CC}, 23-25$ $\mathrm{cm})$. The presence of Globorotalia $(G$. ) tumida plesiotumida without Globigerinoides conglobatus, G. (G.) tumida tumida, Pulleniatina primalis, and Sphaeroidinellopsis paenedehiscens indicates that the assemblages are typical of Zone N17A (late Miocene). These five samples contain Amphistegina radiata (Pl. 1, Fig. 9); Cycloclypeus (C.) carpenteri (PI. 1, Figs. 3, 4) is found in the two lowest samples, and Lepidocyclina (Nephrolepidina) howchini sensu lato (Pl. 1, Figs. 7,10 ) and Operculinella venosa (PI. 1, Figs. 2, 8) occur only in 


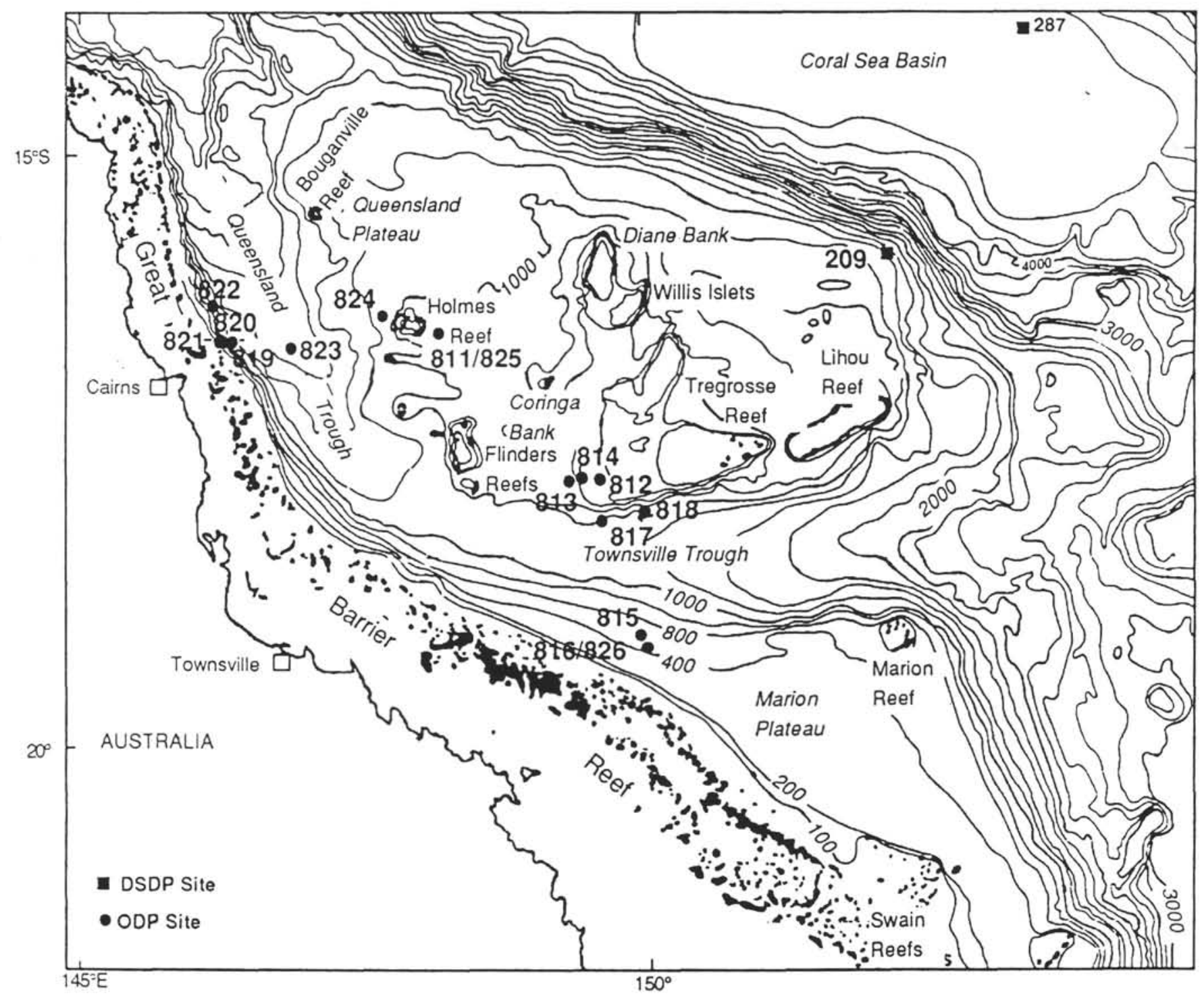

Figure 1. Map of northeastern Australian margin showing Leg 133 drill sites. Bathymetry in meters.

Sample 133-815A-48X-CC, 15-16 cm. With the exception of Lepidocyclina all these shallow-water larger benthic foraminifers range to the Holocene and so could have been contemporaneous with the planktonic faunas. However, $L$. (N.) howchini could only have been derived by reworking from the underlying shallow-water sequence since it is not known elsewhere in the area above Zone N9 (Chaproniere, 1984), suggesting that the other species may also have been reworked. Similar reworking has been observed in dredge samples from the region.

Sample 133-815A-50X-CC, 7-9 cm, was found to contain a substantial number of specimens of Amphistegina radiata and L. (N.) howchini, with rarer Cycloclypeus $(C$.) carpenteri and Sphaerogypsina globula. The majority of specimens of $L$. (N.) howchini had a Parameter F value of 3 ( 36 specimens). This value is typical of levels within Zones N8 and N9 obtained elsewhere in Australia (Chaproniere, 1984). A planktonic assemblage from this sample contains Globigerina (Globoturborotalita) druryi, Globigerinoides bollii, and Globorotalia $(G$.) praemenardii, without $G$. $(G$.) nepenthes, $G$. $(G$.) archeomenardii, G. (G.) lenguaensis, or Globorotalia (Fohsella) spp. $G$. $(G$.) praemenardii ranges from Zones $\mathrm{N} 10$ to $\mathrm{N} 12$ and $G$. $(G$.) archeomenardii to within the top part of Zone N10 (Kennett and Srinivasan, 1983), suggesting a level within the interval of Zones
N11-N12. However, the absence of $G$. (Fohsella) spp., which range to the top of Zone N12, suggests a level within Zone N13. G. (G.) lenguaensis, which also appears at the base of Zone N13, also is absent. Thus, on the basis of this information, this sample has been referred to the zonal interval N11-N12. As noted above, the specimens of $L$. (N.) howchini are typical of those from Zones N8 or N9, and so may have been reworked from the older platform sequence, but note that Palmieri (1971, 1984) recorded Lepidocyclina and Miogypsina from within this interval from the adjacent Aquarius No. 1 Well and the Sandy Cape 1-3R borehole.

\section{Site 816}

Site 816 was drilled through a hemipelagic sequence into a barrier reef section on the edge of the carbonate platform. The platform sequence was dominated by dolomitized coralgal boundstone and framestone, mainly made up of large rhodoliths, which suggests a reefal environment. Recrystallization of the carbonates inhibited foraminiferal identification for many samples.

Nine samples were studied from Hole 816A, 15 from Hole 816B, and 14 from Hole $816 \mathrm{C}$. 


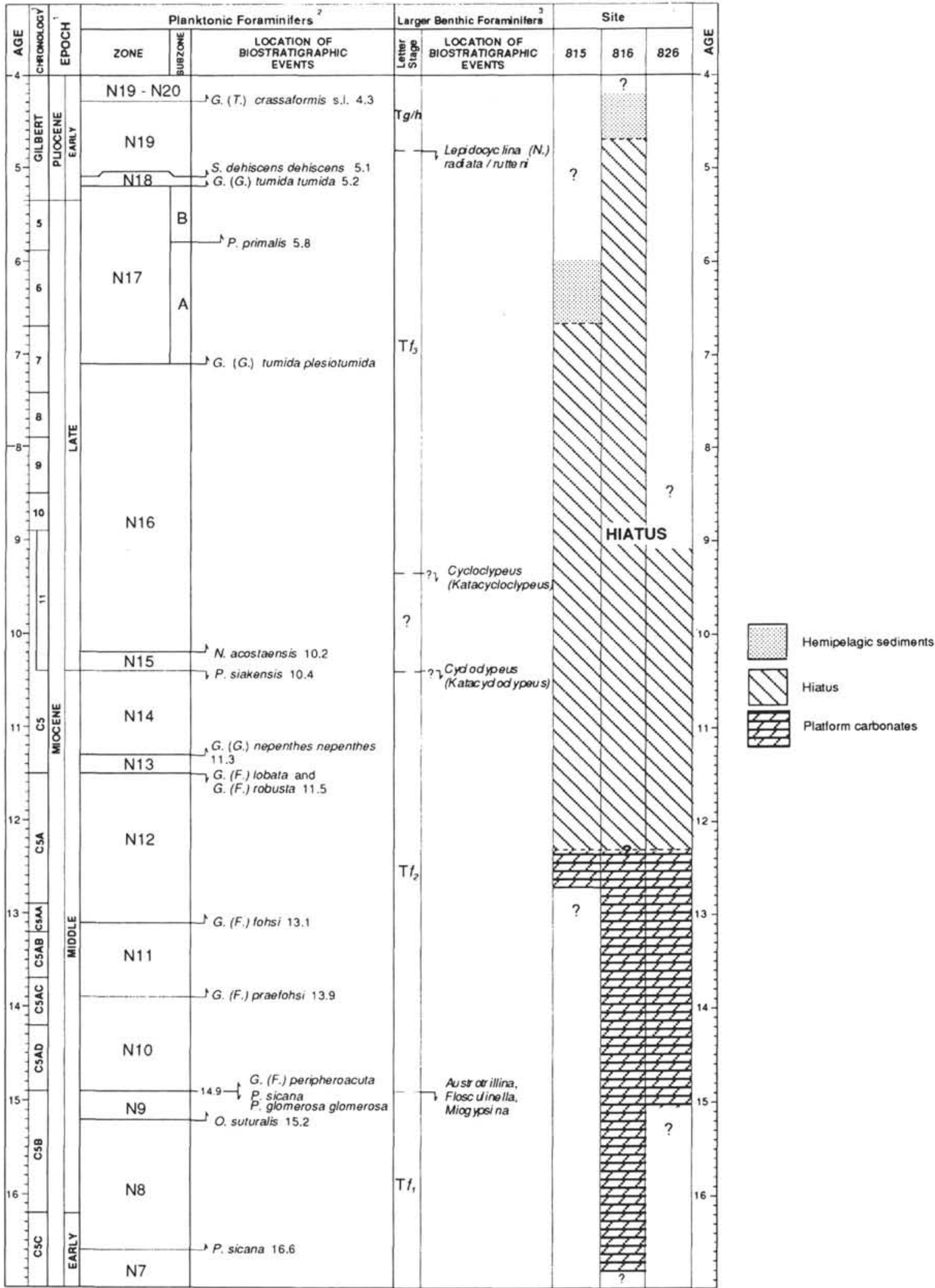

Figure 2. Biostratigraphic summary of Miocene and early Pliocene sections for Sites 815, 816, and 826. 
Table 1. Distribution chart for the Miocene section of Hole 815A.

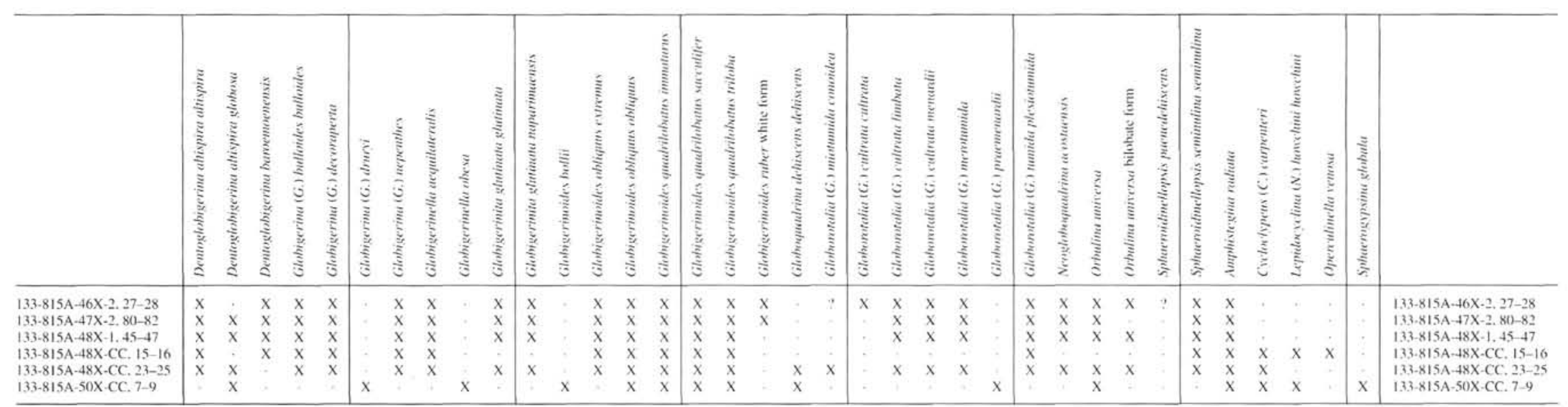




\begin{tabular}{|c|c|c|c|c|c|c|c|c|c|c|c|c|c|c|c|c|c|c|c|c|c|c|c|c|c|c|c|c|c|c|}
\hline & 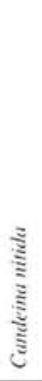 & 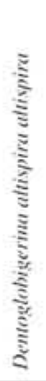 & 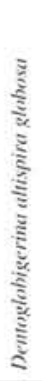 & 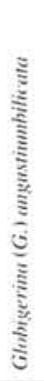 & ט & 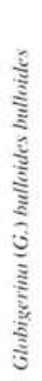 & 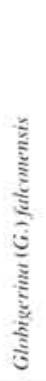 & 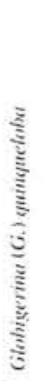 & 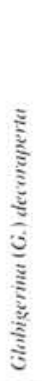 & 脑 & 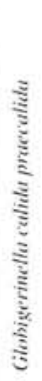 & 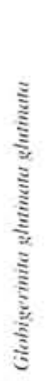 & 离 & 言 & 咅 & 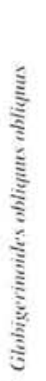 & 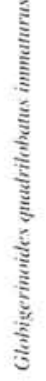 & 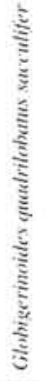 & 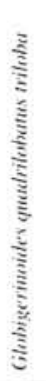 & 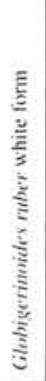 & 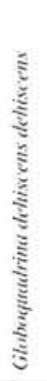 & 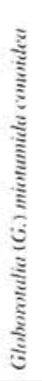 & 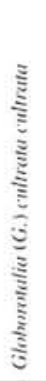 & 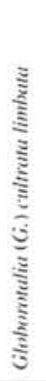 & 㳯 & 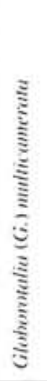 & 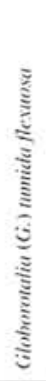 & 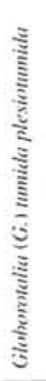 & 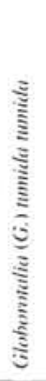 & $\frac{j}{0}$ \\
\hline $133-816 \mathrm{~A}-9 \mathrm{H}-7.65-67$ & $\mathrm{x}$ & $x$ & - & & & $\mathrm{x}$ & $\mathrm{x}$ & $\mathrm{X}$ & $x$ & $\mathrm{x}$ & $\mathrm{x}$ & $\mathrm{x}$ & $\mathrm{x}$ & $\mathrm{x}$ & $\mathrm{x}$ & $x$ & $\mathrm{x}$ & $\mathrm{x}$ & $\mathrm{x}$ & $\mathrm{x}$ & . & . & $\mathrm{x}$ & $\mathrm{x}$ & $\mathrm{x}$ & & & & $x$ & . \\
\hline $133-816 \mathrm{~A}-10 \mathrm{H}-6.70-72$ & & $x$ & $\mathrm{x}$ & $\mathrm{x}$ & ? & $x$ & $x$ & $\mathrm{x}$ & $x$ & $\mathrm{x}$ & $x$ & $\mathrm{x}$ & $\mathrm{x}$ & $\mathrm{x}$ & $x$ & $x$ & $\mathrm{x}$ & $\mathrm{x}$ & $\mathrm{X}$ & & . & $\mathrm{x}$ & $\mathrm{x}$ & $x$ & $x$ & $\mathrm{x}$ & $x$ & & $x$ & \\
\hline $133-816 \mathrm{~A}-10 \mathrm{H}-7,20-22$ & , & $x$ & , & , & . & $\mathrm{x}$ & $\mathrm{x}$ & $\mathrm{x}$ & $\mathrm{x}$ & $x$ & $x$ & $\mathrm{x}$ & $x$ & $x$ & $\mathrm{x}$ & $x$ & $\mathrm{x}$ & $\mathrm{x}$ & $x$ & $\mathrm{x}$ & $x$ & $x$ & $x$ & $x$ & $\mathrm{x}$ & $\mathrm{x}$ & $x$ & & $x$ & \\
\hline $133-816 \mathrm{~A}-11 \mathrm{H}-170-72$ & & & & . & & $x$ & & & & . & & & & & $x$ & & $x$ & & $x$ & & & . & & $x$ & ? & & , & $x$ & & \\
\hline 133-816A-11H-CC. 5-7 & & . & & & & & & & & $=$ & . & & & & . & & & $x$ & & & & & . & & . & . & . & & . & + \\
\hline $133-816 \mathrm{~A}-12 \mathrm{X}-1.16-17$ & & & & & & & & & & is & & . & & & . & & & $x$ & $\mathrm{x}$ & & & & & & & & & & . & $\mathrm{x}$ \\
\hline $133-816 \mathrm{~A}-14 \mathrm{X}-1.7-8$ & & & . & & & . & & . & & . & + & . & & . & . & & & $x$ & & & $\rightarrow$ & & & & & . & & & . & . \\
\hline $133-816$ A-15X-1, $76-78$ & & . & & & & . & & & & . & . & & & & . & & & : & & & . & & & & & & & & & $\therefore$ \\
\hline $133-816 \mathrm{~A}-15 \mathrm{X}-1.90-92$ & . & & . & . & & & & & & $\therefore$ & & & & & ; & & & . & & & & & & & & & & & . & \\
\hline
\end{tabular}

Table 2 (continued).

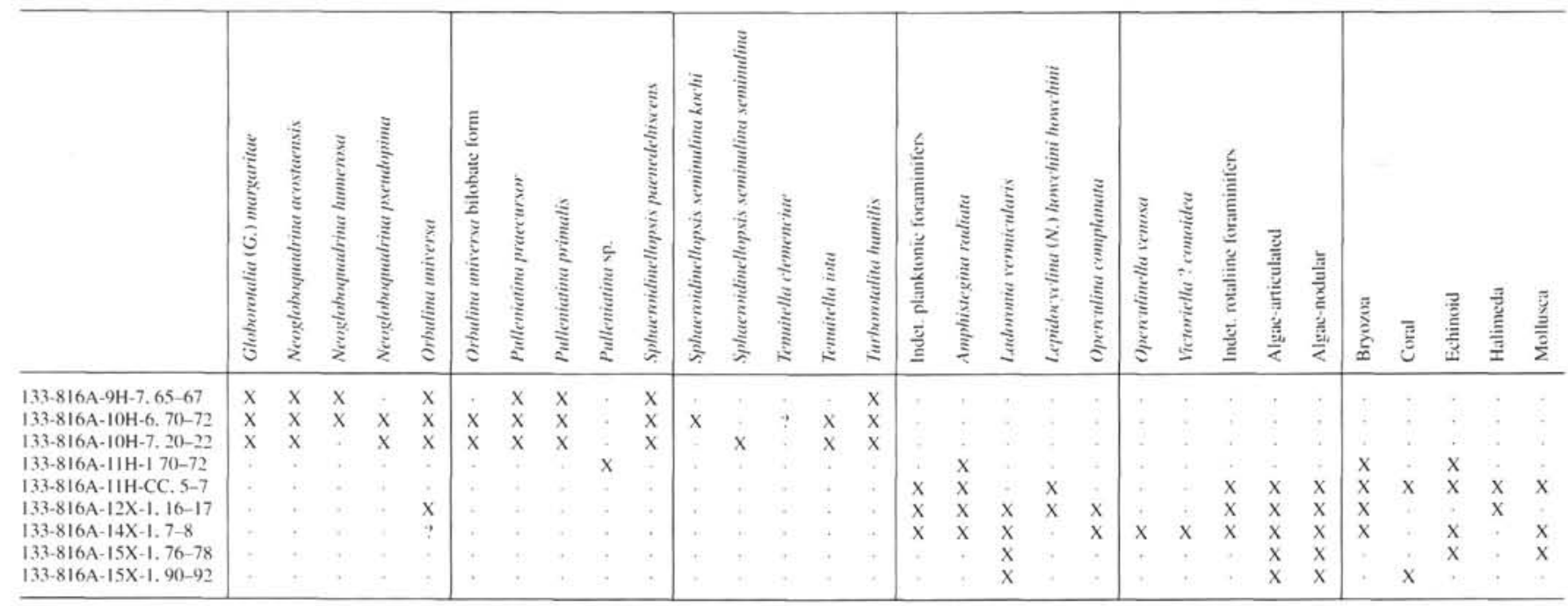

\section{Hole 816 A}

Samples 133-816A-9H-7, 65-67 cm, through - $11 \mathrm{H}-1,70-72 \mathrm{~cm}$, were from the hemipelagic sediments overlying the platform sequence. All but Sample 133-816A-11H-1,70-72 cm, contain diverse, well-preserved faunas with Pulleniatina praecursor, P. primalis, Globorotalia (G.) tumida tumida, G. (Obandyella) margaritae, and Sphaeroidinellopsis paenedehiscens; $G$. (Truncorotalia) crassaformis, P. obliquiloculata, and Sphaeroidinella dehiscens were not identified. The presence of $G$. (G.) tumida plesiotumida and $P$. praecursor without $G$. (T.) crassaformis and $P$. obliquiloculata indicates a level within Zone N19 (early Pliocene). Sample 133-816A-11H-1, 70-72 cm, has a low diversity planktonic fauna that contains Globigerinoides obliquus extremus, G. (G.) tumida plesiotumida, and part of the test of Pulleniatina; this fauna indicates an age no older than Zone N17B, and so is part of the hemipelagic sequence. Amphistegina radiata also is present in this sample, but was absent in the overlying ones. As this sample appears to directly overlie the platform sequence, the Amphistegina may have been derived from the older rocks, but as no older larger benthic foraminifers are present, it is most probably in situ.

Sample 133-816A-11 H-CC, 5-7 cm, and those from Cores 133816-12X through $-15 \mathrm{X}$ were from bioclastic limestones that could only be studied in thin section. The two lowest samples (133-816A$15 \mathrm{X}-1,76-78 \mathrm{~cm}$, and $-15 \mathrm{X}-1,90-92 \mathrm{~cm}$ ) were too recrystallized for faunas to be identified. Planktonics were rare in three samples and absent in the other two. Most could not be identified, except for the long-ranging Globigerinoides quadrilobatus Group, Orbulina universa (Pl. 1, Fig. 11), and a poorly preserved specimen of the $G$. $(G$.) cultrata Group (Pl. 1, Fig. 13), the presence of which indicates an oldest assignment of Zone N10 for Sample 133-816A-12X-1, 16-17 $\mathrm{cm}$. Ladoronia vermicularis (Pl. 1, Fig. 6) is present in all but Sample 133-816A-11H-CC, 5-7 cm, while Amphistegina radiata is present in the upper three samples, and Lepidocyclina $(N$.) howchini (mainly fragments) with Operculinella venosa, Operculina complanata, and Victoriella? conoidea are present in some samples. Because of the poor preservation, Parameter $F$ was measured for one sample (133$816 \mathrm{~A}-12 \mathrm{H}-1,16-17 \mathrm{~cm}$ ) where a mean value of 3 (based on two specimens) was obtained. Ladoronia vermicularis, which is generally a component of the algal nodules, is restricted to the late early and early middle Miocene samples collected by previous dredging operations in the area (Chaproniere and Pigram, in press). Gypsina plana, which is present in the algal nodules from the late Miocene platform limestones, is probably a homomorph of Ladoronia (Chaproniere and Pigram, in press). Thus, the presence of Orbulina, the $G$. (G.) cultrata 


\begin{tabular}{|c|c|c|c|c|c|c|c|c|c|c|c|c|c|c|c|c|c|c|c|c|c|c|}
\hline & 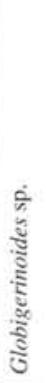 & 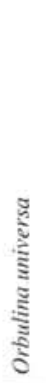 & 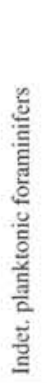 & 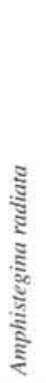 & $\frac{5}{3}$ & 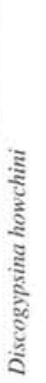 & 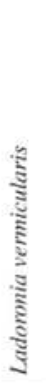 & 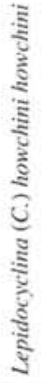 & 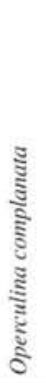 & 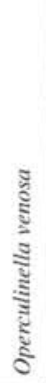 & 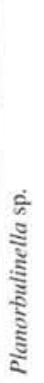 & 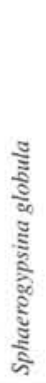 & 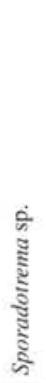 & 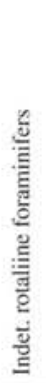 & 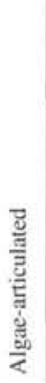 & 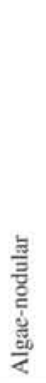 & ¿্ّ & 릉 & 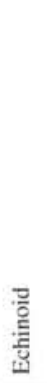 & 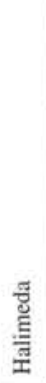 & $\begin{array}{l}\text { 苞 } \\
\frac{\partial}{\bar{z}} \\
\sum\end{array}$ & \\
\hline 133-816B-IR-CC, 8-9 & $\mathrm{x}$ & $?$ & $\mathrm{x}$ & $\mathrm{x}$ & . & . & . & $\mathrm{X}$ & . & $\mathrm{X}$ & . & . & , & $\mathrm{X}$ & $\mathrm{x}$ & $\mathrm{X}$ & $\mathrm{x}$ & $\mathrm{x}$ & $\mathrm{x}$ & $\mathrm{x}$ & $\mathrm{x}$ & 133-816B-1R-CC, 8-9 \\
\hline 133-816B-1R-CC, $20-22$ & . & . & $\mathrm{X}$ & $\mathrm{X}$ & . & $\mathrm{X}$ & . & $\mathrm{X}$ & . & $\mathrm{X}$ & . & . & . & . & . & $\mathrm{X}$ & $\mathrm{X}$ & $\mathrm{X}$ & & $\mathrm{X}$ & $\mathrm{X}$ & 133-816B-IR-CC, 20-22 \\
\hline $133-816 \mathrm{~B}-2 \mathrm{R}-1.47-50$ & . & . & . & $\mathrm{X}$ & ? & . & . & . & . & $?$ & . & . & . & $\mathrm{x}$ & . & $\mathrm{X}$ & . & $\mathrm{X}$ & . & $\mathrm{X}$ & . & $133-816 \mathrm{~B}-2 \mathrm{R}-1,47-50$ \\
\hline $133-816 \mathrm{~B}-2 \mathrm{R}-1,108-110$ & . & & . & $\mathrm{x}$ & . & . & $\mathrm{X}$ & . & . & $\mathrm{X}$ & $\mathrm{x}$ & . & . & $\mathrm{X}$ & . & $\mathrm{x}$ & $\mathrm{X}$ & $\mathrm{x}$ & . & . & . & $133-816 \mathrm{~B}-2 \mathrm{R}-1,108-110$ \\
\hline $133-816 \mathrm{~B}-3 \mathrm{R}-1,10-13$ & . & . & $\mathrm{X}$ & $\mathrm{x}$ & . & . & $\mathrm{X}$ & . & . & $\mathrm{X}$ & . & & . & . & $x$ & $\mathrm{X}$ & . & . & $\mathrm{X}$ & . & $\mathrm{X}$ & $133-816 \mathrm{~B}-3 \mathrm{R}-1,10-13$ \\
\hline $133-816 \mathrm{~B}-3 \mathrm{R}-1,56-58$ & & . & - & ? & $\therefore$ & . & . & . & . & . & . & . & . & . & $\therefore$ & $\mathrm{x}$ & . & . & . & . & $\mathrm{x}$ & $133-816 \mathrm{~B}-3 \mathrm{R}-1,56-58$ \\
\hline $133-816 \mathrm{~B}-4 \mathrm{R}-1.53-56$ & . & . & $\mathrm{X}$ & $\mathrm{X}$ & . & . & $x$ & . & . & . & . & . & , & $\mathrm{X}$ & $\mathrm{x}$ & $\mathrm{X}$ & . & . & $x$ & . & . & $133-816 \mathrm{~B}-4 \mathrm{R}-1,53-56$ \\
\hline 133-816B-7R-1.93-95 & . & . & . & . & . & . & $\mathrm{x}$ & . & . & $\mathrm{x}$ & . & . & . & $\because$ & $\mathrm{X}$ & $\mathrm{X}$ & $\mathrm{X}$ & $\mathrm{X}$ & . & $\mathrm{x}$ & $\mathrm{X}$ & $133-816 \mathrm{~B}-7 \mathrm{R}-1,93-95$ \\
\hline $133-816 \mathrm{~B}-7 \mathrm{R}-1,129-135$ & . & , & . & $\mathrm{x}$ & . & . & $\mathrm{X}$ & . & . & . & , & . & , & , & $\mathrm{x}$ & $\mathrm{X}$ & $\mathrm{X}$ & $\mathrm{X}$ & $\mathrm{X}$ & $\mathrm{x}$ & . & $133-816 \mathrm{~B}-7 \mathrm{R}-1,129-135$ \\
\hline $133-816 \mathrm{~B}-7 \mathrm{R}-1,143-146$ & . & . & . & + & . & . & . & . & . &. & . & . & . & . & $\mathrm{x}$ & $\mathrm{X}$ & . & . & . & . & . & $133-816 \mathrm{~B}-7 \mathrm{R}-1,143-146$ \\
\hline $133-816 \mathrm{~B}-8 \mathrm{R}-1,40-45$ & . & . & $\mathrm{X}$ & . & . & . & $?$ & . & . & $\mathrm{x}$ & . & . & . & . & $\mathrm{x}$ & $\mathrm{X}$ & . & . & $\mathrm{X}$ & . & . & $133-816 \mathrm{~B}-8 \mathrm{R}-1,40-45$ \\
\hline $133-816 \mathrm{~B}-8 \mathrm{R}-1,83-86$ & . & & . & $\mathrm{x}$ & . & . & $?$ & . & . & $\mathrm{X}$ & . & ? & . & . & $\mathrm{X}$ & $\mathrm{X}$ & . & $\mathrm{X}$ & $\mathrm{X}$ & . & $\mathrm{X}$ & 133-816B-8R-1, 83-86 \\
\hline $133-816 \mathrm{~B}-8 \mathrm{R}-1,112-114$ & ? & . & . & $\mathrm{x}$ & : & . & $?$ & . & . & $\mathrm{x}$ & . & . & , & . & $\mathrm{x}$ & $\mathrm{X}$ & . & $\mathrm{X}$ & . & $\mathrm{x}$ & . & $133-816 \mathrm{~B}-8 \mathrm{R}-1,112-114$ \\
\hline $133-816 \mathrm{~B}-8 \mathrm{R}-1.118-120$ & . & & . & . & & & $?$ & . & ? & $\mathrm{x}$ & . & . & . & $\mathrm{x}$ & $\mathrm{X}$ & $\mathrm{X}$ & $\mathrm{x}$ & . & . & $\mathrm{X}$ & $\mathrm{x}$ & $133-816 \mathrm{~B}-8 \mathrm{R}-1,118-120$ \\
\hline $133-816 \mathrm{~B}-8 \mathrm{R}-1,125-127$ & . & & . & $\mathrm{X}$ & . & . & $?$ & . & . & $\mathrm{X}$ & . & ? & ? & . & $\mathrm{X}$ & $\mathrm{x}$ & . & . & $\mathrm{X}$ & $\mathrm{X}$ & . & $133-816 \mathrm{~B}-8 \mathrm{R}-1,125-127$ \\
\hline
\end{tabular}

Group, Ladoronia vermicularis, and $L$. (N.) howchini indicates that these samples are from the older platform phase, and are from the N9-N12 zonal interval.

\section{Hole $816 B$}

Hole $816 \mathrm{~B}$ sampled only the top part of the platform sequence and thus overlaps the lowermost cores of Hole 816A and the topmost part of the section in Hole 816C. Thus, samples from the uppermost cores contain the same assemblage found in the bottom of Hole 816A, Amphistegina radiata, Ladoronia vermicularis, $L$. (N.) howchini, and Operculinella venosa; planktonics are very rare. Although the rocks are recrystallized, a feature that makes the faunas difficult to identify, the bioclasts are dominated by nodular coralline algae, corals, and Halimeda, with foraminifers being very rare. $L$. vermicularis, which encrusts the algal nodules, is the most typical form present. No accurate age assessment could be made, but the presence of $L$. (N.) howchini suggests that this part of the section must be older than Zones N11 to N12.

\section{Hole $816 C$}

This hole continued penetration of the platform section. Cores 133-816C-3R through -6R sampled the same lithologies found in Cores $133-816 \mathrm{C}-7 \mathrm{R}$ and $-8 \mathrm{R}$ in Hole $816 \mathrm{~B}$. This interval is dominated by algal nodules and foraminifers are rare or absent. The interval sampled by Cores $133-816 \mathrm{C}-7 \mathrm{R}$ through $-9 \mathrm{R}$ contain planktonics and rare specimens of $L$. (N.) howchini, with scattered occurrences of $C$. (C.) ?carpenteri; Orbulina appears to be absent, although some specimens of $G$. quadrilobatus (Pl. 1, Fig. 12) were recorded. The specimens of $L$. (N.) howchini have values for Parameter F of 3 , suggesting an assignment to the subspecies praehowchini, a form that is typical of the N5-N7 zonal interval (Chaproniere, 1984). The lowermost samples were recrystallized, making faunal identification impossible.

\section{Site 826}

Only a single hole was drilled at this site, and only the platform sequence was sampled. This hole was drilled to sample a postulated lagoonal sequence adjacent to Site 816 in the belief that better preserved faunas might have been present. As with the other sites, recrystallization made identification of the faunas difficult. The sequence sampled mainly dolomitized bioclastic rudstone and minor coralgal boundstone.

Twenty-three samples from Cores 133-826A-2W through -16R were examined. All samples were studied by thin section. Three samples (with the lowest, Sample 133-826A-12R-1, 4-6 cm) yielded identifiable planktonic faunas that contained $G$. (G.) praemenardii, a form restricted to the N10-N12 zonal interval. Orbulina univers $a$ was found in three samples, with the lowest being Sample 133-826A-14R$1,17-19 \mathrm{~cm}$, indicating Zone N9 or younger. $L .(N$.) howchini is present in Core 133-826A-2W, being absent over the interval from Cores 133-826A-4R through -6R, but is present again in most samples from Cores 133-826A-7R through -14R; this species is rare in all samples, with only one or two specimens present in each. Mean values for Parameter $F$ range from 2 to 3.5. Ladoronia vermicularis is common over the interval of Cores 133-826A-4R through -6R, is absent over the interval of Cores 133-826A-7R through - $12 \mathrm{R}$, then returns in the lowest cores. Only in one sample (133-826A-14R-1, $17-19 \mathrm{~cm}$ ) do both Lepidocyclina and Ladoronia occur together. C. (Katacycloclypeus) annulatus (Pl. 1, Fig. 5), which is present in Sample 133-826A-4R-1, 84-86 cm, ranges to the top of Tf2 (Adams, 1984), and ranges no higher than Zone N15 (Adams, 1984). Thus, the faunas suggest that the lowest samples are best referred to Zone N9 and the highest to within the interval Zone $\mathrm{N} 10-12$.

\section{BIOSTRATIGRAPHIC SUMMARY}

\section{Nonplatform Sequence}

The timing of the initiation of hemipelagic sedimentation over the platform carbonates is different at both Sites 815 and 816 . At Site 815, a late Miocene Zone N17A assemblage is present, but at Site 816 , the oldest fauna is typical of the early Pliocene Zone N19. The result is the same as that obtained from the dredging studies (Chaproniere and Pigram, in press), indicating that flooding of the platform was initiated earlier in the deeper-water Site 815 than in the shallow-water Site 816. The basal samples contain neritic benthic forms (Amphistegina), which may have been reworked from the older platform sequence or may be in situ. 
Table 4. Distribution chart for the Miocene section of Hole 816C.

\begin{tabular}{|c|c|c|c|c|c|c|c|c|c|c|c|c|c|c|c|c|c|c|c|c|c|c|c|c|c|c|c|c|c|c|c|c|c|c|c|c|c|}
\hline & 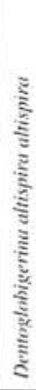 & 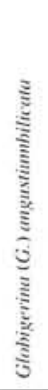 & 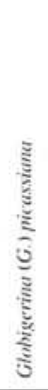 & 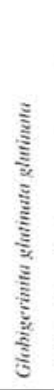 & ' & 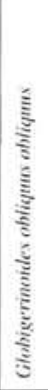 & 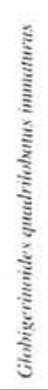 & 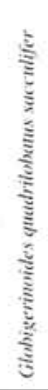 & 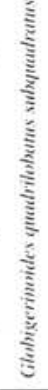 & 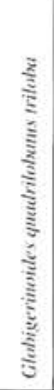 & 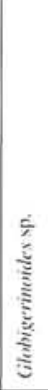 & to & 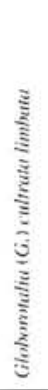 & 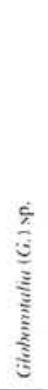 & 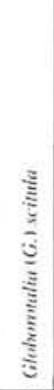 & 童 & 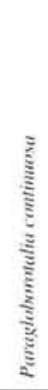 & 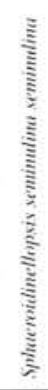 & 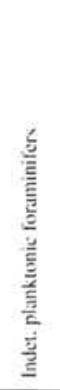 & 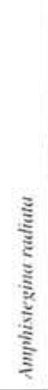 & 玄 & 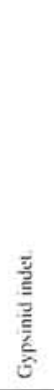 & 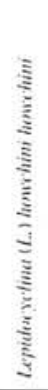 & 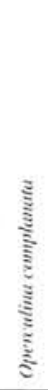 & & t) & $\begin{array}{l}\text { हैँ } \\
\text { है } \\
\text { है } \\
\text { है }\end{array}$ & 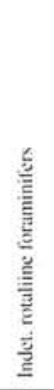 & 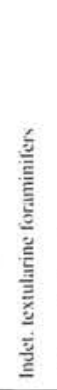 & 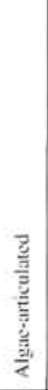 & 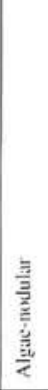 & है & हू & 謩 & 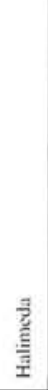 & $\frac{\sqrt{3}}{\frac{z_{2}}{2}}$ & \\
\hline$|33.816 \mathrm{C}-| \mathrm{W}-4.57-6 \mid$ & $x$ & $x$ & $x$ & $x$ & $\mathrm{x}$ & $x$ & $x$ & $x$ & & $x$ & $\mathrm{x}$ & $x$ & $x$ & $x$ & $x$ & $x$ & $?$ & $x$ & $x$ & $x$ & $x$ & $?$ & $\mathrm{x}$ & $x$ & $\mathrm{x}$ & $?$ & & & & $x$ & $x$ & $x$ & $\mathrm{x}$ & $x$ & $\mathrm{x}$ & $x$ & 133-816C-1W-4. 57-61 \\
\hline $133-816 \mathrm{C}-1 \mathrm{~W}-4.67-70$ & & & & & & & & & & & & & & & & & & & & $\mathrm{x}$ & & & & & & & & & & $\mathrm{x}$ & $x$ & $\mathrm{x}$ & $\mathrm{x}$ & $\hat{x}$ & $\mathrm{x}$ & & 133-816C-1W-4, 67-70 \\
\hline $133-816 \mathrm{C}-3 \mathrm{R}-1.61-63$ & & & & & . & & & & & . & & & & & & : & & & & & & & & & & & & & & $\hat{x}$ & $\hat{x}$ & & & & $\hat{x}$ & $\mathrm{x}$ & $133-816 \mathrm{C}-3 \mathrm{R}-1.61-63$ \\
\hline $133-816 \mathrm{C}-4 \mathrm{R}-1.16-20$ & & & & & : & & & & & . & & & & & & . & & & & $\mathrm{x}$ & & & & & $x$ & & & & & $\hat{x}$ & $\hat{x}$ & $\mathrm{x}$ & $\mathrm{x}$ & $\mathrm{x}$ & $\hat{x}$ & & $133-816 \mathrm{C}-4 \mathrm{R}-1.16-20$ \\
\hline $133-816 \mathrm{C}-4 \mathrm{R}-1.68-75$ & & & & & . & & & & & . & & & & & & . & & & & & & & & & $\hat{x}$ & & & & & $\hat{x}$ & $\hat{x}$ & $\lambda$ & $\mathrm{n}$ & $\hat{x}$ & $\hat{x}$ & & $133-816 C-4 R-1.68-75$ \\
\hline $133-816 \mathrm{C}-6 \mathrm{R}-1.9-14$ & & & & & . & & & & & $\therefore$ & & & & & & . & & & $\mathrm{x}$ & & $\therefore$ & & & & $\hat{?}$ & & & $\mathrm{x}$ & & $\hat{x}$ & $\hat{x}$ & $\mathrm{x}$ & & $\hat{x}$ & & $x$ & $133-816 \mathrm{C}-6 \mathrm{R}-1.9-14$ \\
\hline $133-816 \mathrm{C}-6 \mathrm{R}-1.55-57$ & & & & & $\therefore$ & & & & & . & & & & & & : & & & $\mathrm{x}$ & & & & & it & & & & $\mathrm{x}$ & & $\hat{x}$ & $\hat{x}$ & $\lambda$ & & $\lambda$ & & & $133-816$ C-6R-1. 55-57 \\
\hline $\begin{array}{l}133-816 \mathrm{C}-7 \mathrm{R}-1 . \\
-26-28\end{array}$ & & & & & . & & & & $\because$ & $\therefore$ & $x$ & & & & & . & & & $\mathrm{x}$ & $\mathrm{x}$ & $\mathrm{x}$ & & $x$ & & $\mathrm{x}$ & & & $x$ & & $\begin{array}{l}x \\
x\end{array}$ & $\begin{array}{l}x \\
x\end{array}$ & $\mathrm{x}$ & & $\mathrm{x}$ & $\mathrm{x}$ & & $133-816 \mathrm{C}-7 \mathrm{R}-1.26-28$ \\
\hline 133-816C-7R-1. 32-34 & & & & & . & & & & & $\mathrm{x}$ & & & & & & . & & & $\hat{x}$ & $\hat{x}$ & $\hat{x}$ & & $\hat{x}$ & $x$ & & & & $\hat{x}$ & & $\hat{x}$ & $\hat{x}$ & $\hat{x}$ & & $\hat{x}$ & $\mathrm{~A}$ & $x$ & $133-816 \mathrm{C}-7 \mathrm{R}-1.32-34$ \\
\hline $133-816 \mathrm{C}-7 \mathrm{R}-1.4 \mid-44$ & & & & & . & & & & & & & & & & & . & & & & & $\hat{x}$ & & $\hat{x}$ & & $\mathrm{x}$ & & $?$ & & & $\hat{x}$ & $\hat{x}$ & $\hat{x}$ & & $\hat{x}$ & $\mathrm{x}$ & & $133-816 \mathrm{C}-7 \mathrm{R}-1.41-44$ \\
\hline $133-816 \mathrm{C}-8 \mathrm{R}-2.9-11$ & & & & & . & & & & & $\therefore$ & & & & & & . & & & & & & & $\hat{x}$ & & $\hat{n}$ & & & & & $\hat{x}$ & $\hat{x}$ & & $\mathrm{x}$ & $\hat{x}$ & & . & $133-816 \mathrm{C}-8 \mathrm{R}-2.9-11$ \\
\hline $133-816 \mathrm{C}-9 \mathrm{R}-1.6-9$ & & & & & . & & & & & . & & & & & & . & & & & & & & $\hat{x}$ & & & & & & & $\hat{x}$ & $\hat{x}$ & $\mathrm{x}$ & $\hat{x}$ & $\hat{x}$ & $x$ & & $133-816 \mathrm{C}-9 \mathrm{R}-1.6-9$ \\
\hline 133-816C-10R-1.24-26 & & & & & - & & & & & . & & & & & & 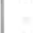 & & & & & & & 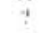 & & $\mathrm{x}$ & & & & $\mathrm{x}$ & $\mathrm{x}$ & $\mathrm{x}$ & $\mathrm{x}$ & & $\mathrm{x}$ & & & $133-816 \mathrm{C}-10 \mathrm{R}-1.24-26$ \\
\hline $133-816 \mathrm{C}-11 \mathrm{R}-1.140-143$ & & & & & . & & & & & . & & & & & & & & & $\mathrm{x}$ & & & & & & $\mathrm{x}$ & & & & & $\mathrm{x}$ & $\mathrm{x}$ & $\mathrm{x}$ & $\mathrm{x}$ & & $\mathrm{x}$ & & $133-816 \mathrm{C}-1 / \mathrm{R}-1.140-143$ \\
\hline
\end{tabular}


Table 5. Distribution chart for the Miocene section of Hole 826A.

\begin{tabular}{|c|c|c|c|c|c|c|c|c|c|c|c|c|c|c|c|c|c|c|c|c|c|c|c|c|c|c|c|c|c|c|c|c|c|}
\hline & 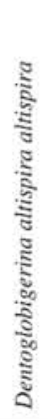 & 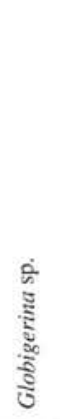 & 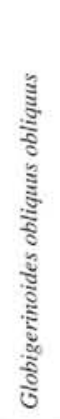 & 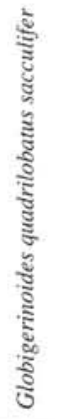 & 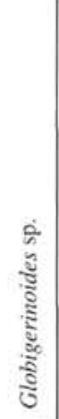 & 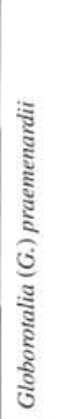 & 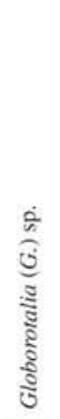 & 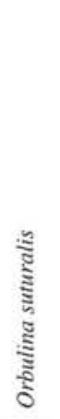 & 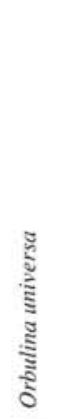 & 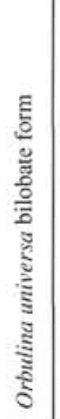 & 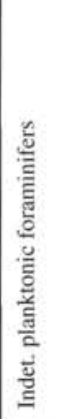 & 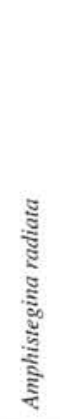 & 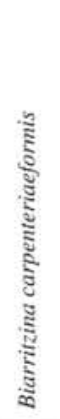 & 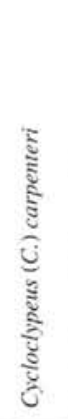 & 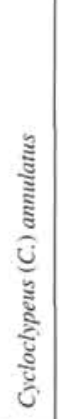 & 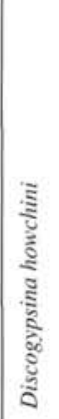 & 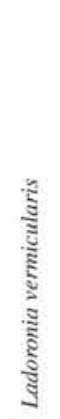 & 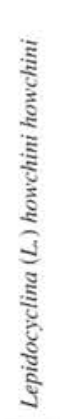 & 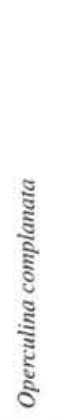 & 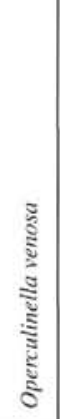 & 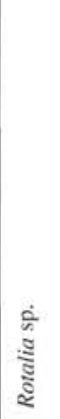 & 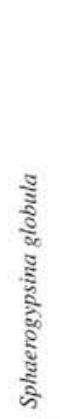 & 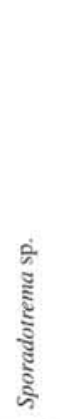 & 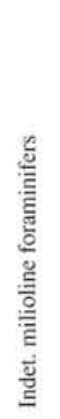 & 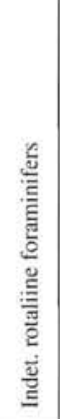 & 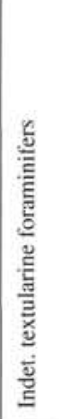 & 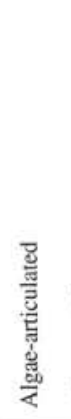 & 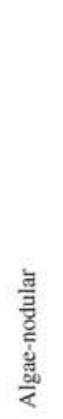 & 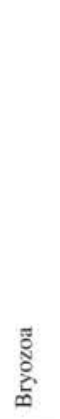 & एँّ & 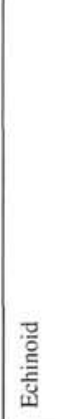 & 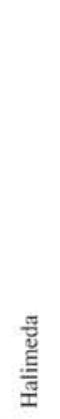 & $\begin{array}{l}\text { 苟 } \\
\text { 总 } \\
\text { 之o }\end{array}$ \\
\hline 135-826A-2W-CC, 5-7 & & $\mathrm{x}$ & $\mathrm{x}$ & & $\mathrm{x}$ & . & $\mathrm{x}$ & & & . & $\mathrm{x}$ & $\mathrm{x}$ & & & . & . & & $\mathrm{x}$ & . & $\mathrm{x}$ & . & . & ? & . & . & & $\mathrm{x}$ & $\mathrm{x}$ & & & $\mathrm{x}$ & $\mathrm{x}$ & $\mathrm{x}$ \\
\hline 13 & & : & & & $\because$ & & : & & . & . & & & & . & ${ }^{*}$ & & . & $\mathrm{x}$ & & & & $\mathrm{x}$ & & & & & ${ }^{-}$ & & 5 & & & & \\
\hline $135-826 \mathrm{~A}-2 \mathrm{~W}-\mathrm{CC}, 12$ & $\mathrm{x}$ & & . & . & $\mathrm{x}$ & $\mathrm{x}$ & & & $\mathrm{x}$ & $\mathrm{x}$ & $\mathrm{x}$ & $x$ & & & . & & & $\mathrm{x}$ & $\mathrm{x}$ & & & & ? & & $\mathrm{x}$ & & $\mathrm{x}$ & & $x$ & $\mathrm{x}$ & & $\mathrm{x}$ & . \\
\hline $135-826 \mathrm{~A}-4 \mathrm{R}-1,16-18$ & & . & . & . & $\because$ & . & & & . & . & . & $\hat{x}$ & . & $\mathrm{x}$ & . & . & $\mathrm{x}$ & $\because$ & : & $\lambda$ & & & & $\mathrm{x}$ & x & & $\mathrm{x}$ & $\mathrm{x}$ & $\hat{x}$ & $\hat{x}$ & $\hat{x}$ & $\hat{x}$ & $\mathrm{x}$ \\
\hline 13 & & & & & . & & & & & . & . & $\mathrm{x}$ & & & . & . & $\mathrm{x}$ & & & $\mathrm{x}$ & & & & & $\mathrm{x}$ & . & $x$ & & $\mathrm{x}$ & $\mathrm{x}$ & $\mathrm{x}$ & $\mathrm{x}$ & $\mathrm{x}$ \\
\hline 13 & & . & . & . & . & & & & & . & & $x$ & & 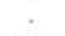 & & 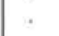 & & & . & $\mathrm{x}$ & & & . & & & & & $x$ & & & & & $\mathrm{x}$ \\
\hline $4,-1,184$ & & & & & . & . & & . & . & . & $\mathrm{x}$ & $\mathrm{x}$ & $x$ & $\mathrm{x}$ & $\mathrm{x}$ & . & & & ? & ? & . & & & $\mathrm{x}$ & $\mathrm{x}$ & . & $\mathrm{x}$ & $\mathrm{x}$ & $\mathrm{x}$ & & $\mathrm{x}$ & $\mathrm{x}$ & $\mathrm{x}$ \\
\hline & 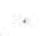 & . & . & ? & . & & & & & . & . & $x$ & . & . & ? & . & & & : & $\mathrm{x}$ & . & . & . & & & . & $\mathrm{x}$ & $\mathrm{x}$ & k & & & $\mathrm{x}$ & $\mathrm{x}$ \\
\hline AA-5R-1, 19-21 & & & & & . & & & & . & . & . & $\mathrm{x}$ & & $\mathrm{x}$ & . & & & . & . & ?. & 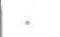 & . & & $x$ & $\mathrm{x}$ & . & & $\mathrm{x}$ & $\mathrm{x}$ & $\mathrm{x}$ & & $\mathrm{x}$ & $\mathrm{x}$ \\
\hline & $x$ & & & . & $x$ & $\mathrm{x}$ & . & . & $\mathrm{x}$ & . & $\mathrm{x}$ & & $\mathrm{x}$ & & . & & $x$ & . & . & . & . & & . & & $x$ & . & $\mathrm{x}$ & & $x$ & & $\mathrm{x}$ & $\mathrm{x}$ & $\mathrm{x}$ \\
\hline & & & & & ? & & & . & & . & ?. & $\mathrm{x}$ & & & . & & $x$ & . & & . & . & . & & . & $x$ & $c_{0}+$ & & $x$ & & & $\mathrm{x}$ & $\mathrm{x}$ & : \\
\hline $1-4$ & & . & , & . & . & & . & & & . & $\mathrm{x}$ & $\mathrm{x}$ & & & . & . & ? & $\mathrm{x}$ & & $\mathrm{x}$ & & $\mathrm{x}$ & & & & $\mathrm{x}$ & $\mathrm{x}$ & $\mathrm{x}$ & $\mathrm{x}$ & . & $\mathrm{x}$ & & . \\
\hline & & & . & & . & 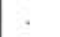 & & . & . & . & ? & $\mathrm{x}$ & ? & $\mathrm{x}$ & . & . & . & $\because$ & $\mathrm{x}$ & $\mathrm{x}$ & $\mathrm{x}$ & : & . & $\mathrm{x}$ & $\mathrm{x}$ & $\mathrm{x}$ & & $x$ & $\mathrm{x}$ & . & & $\mathrm{x}$ & $\mathrm{x}$ \\
\hline $135-8$ & 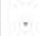 & . & . & . & . & & . & $=$ & 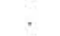 & . & . & $\mathrm{x}$ & & & . & & & & : & & & & & & . & . & $\mathrm{x}$ & & & & & & ? \\
\hline & & & & & $\mathrm{x}$ & . & & . & . & . & $\mathrm{x}$ & , & & . & . & 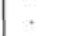 & & $\mathrm{x}$ & $\mathrm{x}$ & $\mathrm{x}$ & . & . & . & $\mathrm{x}$ & . & . & $\mathrm{x}$ & $\mathrm{x}$ & $\mathrm{x}$ & & $\mathrm{x}$ & $\mathrm{x}$ & \\
\hline & & & & . & & . & . & & . & . & $\mathrm{x}$ & , & & & . & 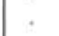 & & & & 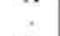 & . & & & & . & 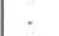 & $\mathrm{x}$ & & & & $\mathrm{x}$ & & $\mathrm{x}$ \\
\hline & & & . & & $\mathrm{x}$ & . & & . & . & . & $\mathrm{x}$ & ; & & & . & & & $\mathrm{x}$ & . & $\mathrm{x}$ & 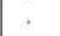 & . & . & . & & $\mathrm{x}$ & $\mathrm{x}$ & $\mathrm{x}$ & $\mathrm{x}$ & & $x$ & $\mathrm{x}$ & $\mathrm{x}$ \\
\hline & & & . & . & & . & $\mathrm{x}$ & . & & . & $\mathrm{x}$ & $\mathrm{x}$ & & $\mathrm{x}$ & . & . & & $\mathrm{x}$ & . & & . & & & & $\mathrm{x}$ & . & $\mathrm{k}$ & & $x$ & & . & & $\mathrm{x}$ \\
\hline & & & . & . & $\mathrm{x}$ & $\mathrm{x}$ & . & . & & . & $\mathrm{x}$ & $\mathrm{x}$ & & $x$ & $\mathrm{x}$ & . & & $\mathrm{x}$ & $\mathrm{x}$ & $\mathrm{x}$ & . & . & & & & . & $\mathrm{x}$ & $\mathrm{x}$ & & & . & $\mathrm{x}$ & $\mathrm{x}$ \\
\hline & & & . & . & . & ? & & & . & . & & . & & $\mathrm{x}$ & . & . & $\mathrm{x}$ & & & . & . & & & & $\mathrm{x}$ & . & & $\mathrm{x}$ & $\mathrm{x}$ & & & & \\
\hline $135-826 \mathrm{~A}-14 \mathrm{R}-1,12-14$ & & & & . & . & . & . & . & & . & $\mathrm{x}$ & $\mathrm{x}$ & $\mathrm{x}$ & $\mathrm{x}$ & . & . & . & $\mathrm{x}$ & $\mathrm{x}$ & . & . & $\mathrm{x}$ & & . & $\mathrm{x}$ & . & $\mathrm{x}$ & $\mathrm{x}$ & $\mathrm{x}$ & . & $\mathrm{x}$ & $\mathrm{x}$ & $\mathrm{x}$ \\
\hline & & & . & & $\mathrm{x}$ & . & & ? & $x$ & . & $\mathrm{x}$ & $\hat{x}$ & & $\mathrm{x}$ & . & . & $\mathrm{x}$ & $\mathrm{x}$ & $\because$ & $\mathrm{x}$ & . & & . & . & $x$ & . & & & & . & $\mathrm{x}$ & : & $\mathrm{x}$ \\
\hline $135-826 \mathrm{~A}-16 \mathrm{R}-\mathrm{CC}, 10-13$ & & . & & & & & . & & ?. & & $\because$ & $\mathrm{x}$ & & & & & $x$ & & & $\hat{x}$ & . & . & & . & & & $x$ & $x$ & $x$ & & $x$ & & $\mathrm{x}$ \\
\hline
\end{tabular}




\section{Platform Sequence}

In general, the faunas from the platform carbonates were poorly preserved due to dolomitization effects that sometimes destroyed the fossils, making identification impossible. Planktonic species do occur within the sequence with the key forms being Globorotalia $(G$.) praemenardii and Orbulina universa (PI. 1, Figs. 11, 13), indicating the interval Zones N11-N12 and N9 or younger, respectively. Orbulina appears within the upper part of the platform section of Site 816, suggesting that those samples below this event should be referred to the interval Zone N5-N8. Lepidocyclina $(N$.) howchini is rare and scattered, with mean values of Parameter $F$ ranging from 2 (based on single specimens) to 3.3. From previous results (Chaproniere, 1981, 1984), these values are typical of Zones N5-N8 for the region. Ladoronia vermicularis, an encrusting form found within algal nodules, is an important index for these platform sediments. As for the hemipelagic sequence, the biostratigraphic results are in accord with those obtained from the dredging studies (Chaproniere and Pigram, in press).

\section{PALEOENVIRONMENTS}

\section{Carbonate Platform Sequence}

For all sites, the early middle Miocene carbonates are dominated by coralline algae, with Halimeda and corals often being important. Amphistegina is the most widespread benthic foraminiferal component, but locally Ladoronia vermicularis is also common. Planktonic foraminifers are rare and scattered.

\section{Site 815}

Only the top $9 \mathrm{~m}$ of the shallow-water carbonate section was penetrated. The presence of Amphistegina, Cycloclypeus carpenteri, Lepidocyclina $(N$.) howchini, and Operculinella venosa indicates water depths within the euphotic zone, that is less than $\sim 120 \mathrm{~m}$. On the other hand, seismic data suggest that Site 815 was located in a forereef setting. The large number of planktonic forms and the absence of coral and algal bioclasts support a forereef environment, and it is probable that the larger foraminifers have been reworked into deeper water.

\section{Site 816}

In contrast to Site 815 , Site 816 was drilled in a backreef location. The carbonates of Site 816 contain a low number of planktonic species but large amounts of coralline algae (both nodular and articulated), Halimeda, and corals. The presence of the planktonic forms and rarity of milioline foraminifers suggests normal oceanic salinities. The presence of Halimeda, the coralline algae, corals, and larger benthic forms, such as Cycloclypeus $(C$.) carpenteri, $L$. $(N$.) howchini, Operculina complanata, and Operculinella venosa, suggests water depths somewhat $<50 \mathrm{~m}$. The biotic assemblages are consistent with having been deposited in a backreef environment. The rarity or absence of $L$. (N.) howchini when Ladoronia vermicularis is present suggests environmental control, but the factors controlling this distribution are not known. The fact that $L$. vermicularis grows within algal nodules suggests that this species may grow best at depths that may have been too shallow for Lepidocyclina to survive.

\section{Site 826}

Planktonic foraminifers are slightly more common at Site 826 than at Site 816. The presence of Globorotalia $(G$.) praemenardii (a keeled form) suggests either slightly greater water depths, or a more direct access to open oceanic conditions. Support for this comes from the distribution of corals; these are distributed throughout the carbonate section at Site 816 , but are present only at the topmost part of the sequence at Site 826. Miliolines form an insignificant faunal component, and this characteristic together with the presence of planktonic species indicates normal ocean salinities. The almost ubiquitous presence of Halimeda and coralline algae indicates depths of $<60 \mathrm{~m}$ (Davies and Marshall, 1985). Although larger benthic forms $C$. (C.) carpenteri, C. (Katacycloclypeus) annulatus, L. (N.) howchini, Ladoronia vermicularis, Operculina complanata, and Operculinella venosa are present, they are never abundant. Amphistegina radiata is the most widely distributed benthic foraminifer. The low numbers of these foraminifers suggest shallow-water depths of probably $<50 \mathrm{~m}$. The general biotic assemblage is consistent with a backreef environmental setting. As for Site 816, Ladoronia and Lepidocyclina rarely occur together

\section{Hemipelagic Sediments}

The hemipelagic sediments overlying the carbonate platform sediments at Sites 815 and 816 have a similar faunal component; no samples of this part of the sequence were recovered at Site 826. The sediments immediately overlying the shallow-water carbonates at Site 816 do contain specimens of Amphistegina radiata, without any of the older forms, such as Lepidocyclina, which suggests that these are in situ. At Site 815, Amphistegina also is present, but with $C$. $(C$.) carpenteri and $L$. (N.) howchini, suggesting that reworking from the older sequence has occurred. Nevertheless, the presence of these shallow-water forms indicates that when the platform was flooded, depths were very shallow for only a short period of time, but by the time Core 133-815A-45X was deposited, water depths were at outer neritic levels (Shipboard Scientific Party, 1990, p. 996).

\section{CONCLUSIONS}

The carbonate platform making up the northern end of the Marion Plateau contains foraminifers that indicate that it was constructed from at least Zone N8, and possibly from Zone N5, to within the Zone N11-12 interval. Water depths at the different sites varied from $\sim 100$ $\mathrm{m}$ at Site 815 to somewhat less than $50 \mathrm{~m}$ at Sites 816 and 826 . Normal oceanic salinities prevailed. Sedimentation ceased when the platform was exposed for a long period, throughout most of the middle and late Miocene. Sedimentation resumed during the late Miocene Zone N17A at Site 815 on the edge of the platform, and resumed in the Pliocene Zone N19 at Site 816 on the top of the platform. Water depths over the platform increased rapidly to outer neritic depths.

\section{ACKNOWLEDGMENTS}

We thank the reviewers, C.G. Adams, P.J. Coleman, and D.W. Haig, for their valuable comments. G.C. Chaproniere publishes with the permission of the Executive Director, Bureau of Mineral Resources, Canberra, Australia. C. Betzler acknowledges the financial support provided by the Deutsche Forschungsgemeinschaft.

\section{REFERENCES}

Adams, C.G., 1984. Neogene larger foraminifera, evolutionary and geological events in the context of datum planes. In Ikebe, N., and Tsuchi, R. (Eds.), Pacific Neogene Datum Planes: Contributions to Biostratigraphy and Chronology: Tokyo (Univ. of Tokyo Press), 47-67.

Blow, W.H., 1969. Late middle Eocene to Recent planktonic foraminiferal biostratigraphy. In Brönniman, P., and Renz, H.H. (Eds.), Proc. First Int. Conf. Planktonic Microfossils, Geneva, 1967: Leiden (E.J. Brill), 1:199-422.

Chaproniere, G.C.H., 1981. Late Oligocene to early Miocene planktonic foraminifers from Ashmore Reef No. 1 well, northwest Australia. Alcheringa, 5:103-131.

, 1984. Oligocene and Miocene larger foraminiferida from Australia and New Zealand. Bull.-Bur. Miner. Resour., Geol. Geophys. (Aust.), 188:1-98.

\footnotetext{
- Abbreviations for names of organizations and publication titles in ODP reference lists follow the style given in Chemical Abstracts Service Source Index (published by American Chemical Society).
} 
Chaproniere, G.C.H., and Pigram, C.J., in press. AGSO J. Austral. Geo. Geophys., 14(2).

Davies, P.J., and Marshall, J., 1985. Halimeda bioherms-low energy reefs, northern Great Barrier Reef. Proc. 5th Coral Reef Symp., 5:1-7.

Davies, P.J., McKenzie, J.A., Palmer-Julson, A., et al., 1991. Proc. ODP, Init. Repts., 133: College Station, TX (Ocean Drilling Program).

Kennett, J.P., and Srinivasan, M.S., 1983. Neogene Planktonic Foraminifera: A Phylogenetic Atlas: Stroudsburg, PA (Hutchinson Ross).

Palmieri, V., 1971. Tertiary subsurface biostratigraphy of the Capricorn Basin. Rep.-Geol. Surv. Queensl., 52:1-18.

1984. Neogene Foraminiferida from GSQ Sandy Cape 1-3R bore, Queensland: a biostratigraphic appraisal. Palaeogeogr., Palaeoclimatol., Palaeoecol., 46:165-183.

Shipboard Scientific Party, 1990. Leg 133 preliminary report. ODP Prelim. Rept., 33:1-94.

Date of initial receipt: 23 March 1992

Date of acceptance: 10 November 1992

Ms 133SR-212

\section{APPENDIX}

\section{LIST OF FORAMINIFERS}

Larger Benthic Foraminifers

Amphistegina radiata (Fichtel and Moll, 1798)

Biarritzina carpenteriaeformis (Halkyard, 1918)

Cycloclypeus (Cycloclypeus) carpenteri Brady, 1881

Cycloclypeus (Katacycloclypeus) annulatus Martin, 1880

Discogypsina howchini (Chapman, 1910)

Ladoronia vermicularis Hanzawa, 1957

Lepidocyclina (Nephrolepidina) howchini sensu lato Chapman and Crespin, 1932

Operculina complanata (Defrance, 1822)

Operculinella venosa (Fichtel and Moll, 1798)

Sphaerogypsina globula (Reuss, 1848)

Victoriella conoidea (Rutten, 1914)

Planktonic Foraminifers

Candeina nitida d'Orbigny, 1839

Dentoglobigerina altispira altispira (Cushman and Jarvis, 1936)

Dentoglobigerina altispira globosa (Bolli, 1957)

Dentoglobigerina baroemoenensis (LeRoy, 1939)

Globigerina (Globigerina) angustiumbilicata Bolli, 1957
Globigerina (Globigerina) bulbosa LeRoy, 1944

Globigerina (Globigerina) bulloides bulloides d'Orbigny, 1826

Globigerina (Globigerina) falconensis Blow, 1959

Globigerina (Globigerina) quinqueloba Natland, 1938

Globigerina (Globoturborotalita) decoraperta Takayanagi and Saito, 1962

Globigerina (Globoturborotalita) druryi Akers, 1955

Globigerina (Globoturborotalita) nepenthes Todd, 1957

Globigerinella aequilateralis (Brady, 1879)

Globigerinella calida praecalida (Blow, 1969)

Globigerinella obesa (Bolli, 1957)

Globigerinita glutinata glutinata (Egger, 1893)

Globigerinita glutinata naparimaensis Brönnimann, 1951

Globigerinoides bollii Blow, 1959

Globigerinoides conglobatus (Brady, 1879)

Globigerinoides obliquus extremus Bolli and Bermudez, 1965

Globigerinoides obliquus obliquus Bolli, 1957

Globigerinoides quadrilobatus immaturus LeRoy, 1939

Globigerinoides quadrilobatus sacculifer (Brady, 1877)

Globigerinoides quadrilobatus subquadratus Brönnimann, 1954

Globigerinoides quadrilobatus triloba (Reuss, 1850)

Globigerinoides ruber white form (d'Orbigny, 1839)

Globoquadrina dehiscens dehiscens (Chapman et al., 1934)

Globorotalia (Globoconella) miotumida conoidea Walters, 1955

Globorotalia (Globorotalia) cultrata cultrata (d'Orbigny, 1839)

Globorotalia (Globorotalia) cultrata limbata (Fornasini, 1902)

Globorotalia (Globorotalia) cultrata menardii (Parker et al., 1865)

Globorotalia (Globorotalia) merotumida Blow and Banner, 1965

Globorotalia (Globorotalia) multicamerata Cushman and Jarvis, 1930

Globorotalia (Globorotalia) praemenardii Cushman and Stainforth, 1945

Globorotalia (Globorotalia) tumida flexuosa (Koch, 1923)

Globorotalia (Globorotalia) tumida plesiotumida Blow and Banner, 1965

Globorotalia (Globorotalia) tumida tumida (Brady, 1877)

Globorotalia (Obandyella) margaritae Bolli and Bermudez, 1965

Globorotalia (Obandyella) scitula (Brady, 1882)

Neogloboquadrina acostaensis (Blow, 1959)

Neogloboquadrina humerosa (Takayanagi and Saito, 1962)

Neogloboquadrina pseudopima (Blow, 1969)

Orbulina universa d'Orbigny, 1839

Orbulina universa bilobate form d'Orbigny, 1839

Paragloborotalia continuosa (Blow, 1959)

Pulleniatina praecursor Banner and Blow, 1967

Pulleniatina primalis Banner and Blow, 1967

Sphaeroidinellopsis paenedehiscens Blow, 1969

Sphaeroidinellopsis seminulina kochi (Caudri, 1934)

Sphaeroidinellopsis seminulina seminulina (Schwager, 1866)

Tenuitella clemenciae (Bermudez, 1961)

Tenuitella iota (Parker, 1962)

Turborotalita humilis (Brady, 1884) 

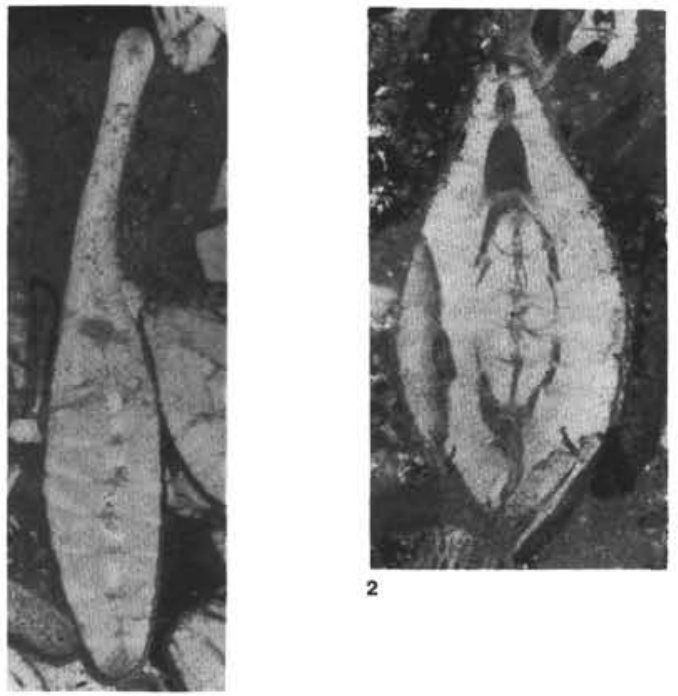

2
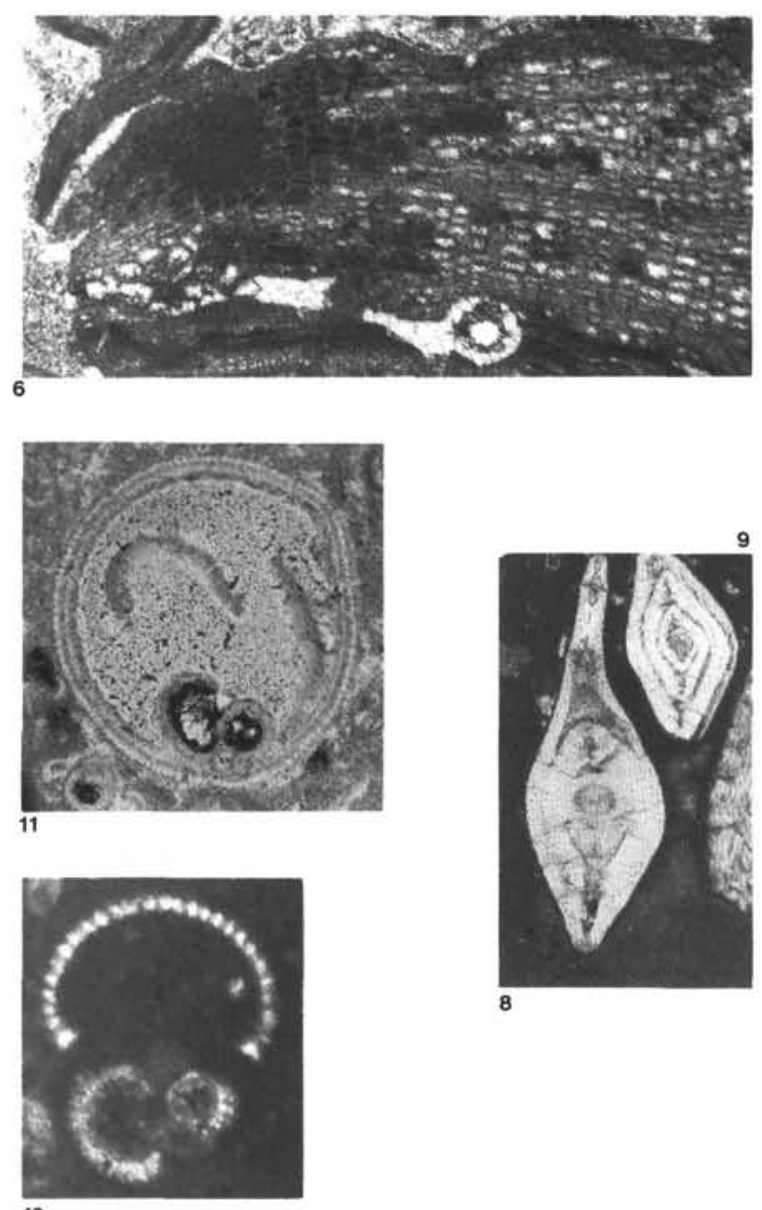

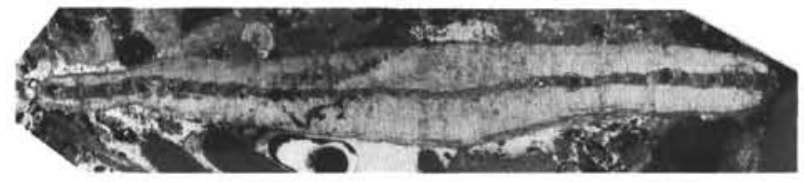

3
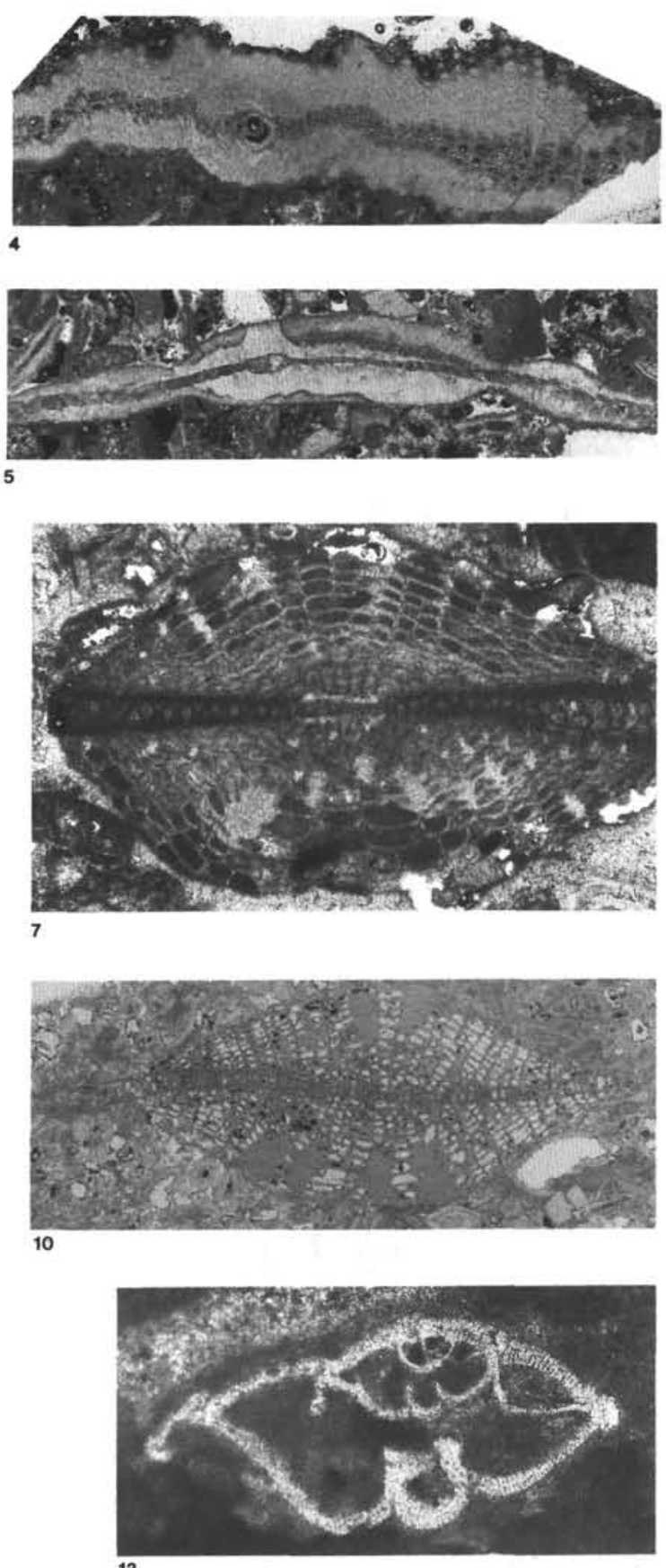

13

Plate 1. 1. Operculina complanata (Defrance, 1822), off-center vertical section, $\times 17$; Sample 133-826A-2W-CC, 5-7 cm, CPC23256. $2, \mathbf{8}$. Operculinella venosa (Fichtel and Moll, 1798), off-center vertical sections, $\times 30$; Sample 133-826A-12R-1, 4-6 cm, CPC23257, CPC23263. 3. Cycloclypeus (Cycloclypeus) carpenteri Brady, 1881, off-center vertical section, x17; Sample 133-826A-12R-1, 4-6 cm, CPC23258. 4 . Cycloclypeus (Cycloclypeus) carpenteri Brady, 1881, oblique equatorial section, $\times 17$; Sample 133-826A-12R-1, 4-6 cm, CPC23259. 5. Cycloclypeus (Katacycloclypeus) carpenteri Martin, 1880, off-center vertical section, $\times 17$; Sample 133-826A-12R-1, 4-6 cm, CPC23260. 6. Ladoronia vermicularis Hanzawa, 1957, random section through encrusting mass, $\times 30$; Sample 133-816B-4R-1, 16-17 cm, CPC23261. 7, 10 . Lepidocyclina (Nephrolepidina) howchini Chapman and Crespin, 1932, off-center vertical sections, $\times 30, \times 17$; Sample 133-826A-11R-1, 54-55 $\mathrm{cm}$, CPC23262, Sample 133-815A-50X-CC, 7-9 cm, CPC23265. 9. Amphistegina radiata Terquem, 1881, off-center vertical section, $\times 30$; Sample 133-826A-2W-CC, 10-15 cm, CPC23264. 11. Orbulina? universa d'Orbigny, 1839, transverse section, $\times 50$; Sample 133-815A-50X-CC, 7-9 cm, CPC23266. 12. Globigerinoides sp., transverse section, $\times 95$; Sample 133-816C-7R-1, 32-34 cm, CPC23267. 13. Globorotalia (Globorotalia) sp., vertical section, $\times 80$; Sample 133-826A-11R-1, 58-60 cm, CPC23268. 